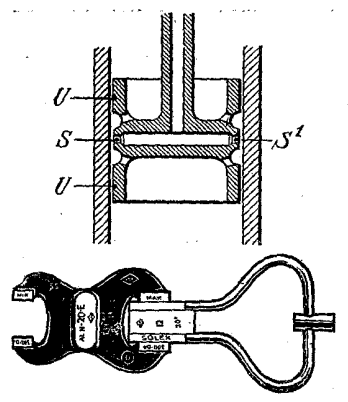

第 3 圖（上）第 4 圖 (下)
名深起没し水の表面は大完 区にさらし、区縮空气は $T$ の中で膨脹して区压力は $R$ 中の水頭 $H$ で決められ餘 分の空兮は水を通して逃げ る。かくて一定匡 $H$ が保 たれる。んは垂直ゲーデ $M$ の上で讀みこれから $d$ を

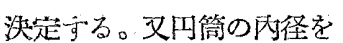
測る栓グーデに應用ずる事 6出來、第3 圖は之の例である。測定の精度は $1 / 1,000 \mathrm{~mm}$ を越一る事は容易であつて、取着方によつては $1 / 20,000 \mathrm{~mm}$ まで讀む事が出來る。第4圖は普通の限界ぶーゲの較正に應 用した例である。

(福苏)

\section{[202] 膜模型による揄り內力の決定法}

[V. D. I. Bd. 78, Nr. 30, 1934-6, 頁 913 914, 圆 7.]

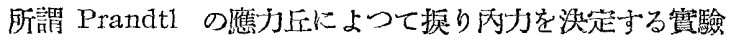
法の 1 つであつて、第 1 圖は裝置の略圖を示し $a$ は研究し

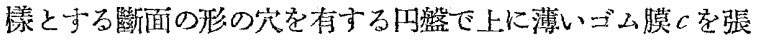
り需 $b$ の上に取着け，板 $d$, リング $e$ 及び $c$ の間に可塑性物 質 $g$ を入れ、文 $b$ の内水を入れ、次に $d$ と $e$ によて $g$ を $c$ に压し付けると $c$ は压力质を示し $g$ でその型をとり、 次にコックんから水を出し又gをかめでごと取はずす。 $g$ の比雪は水と相等しい事が必要であつてバラフィンの混合 物で造る事が出來る。かくて應力后の等高線から主揬り內力

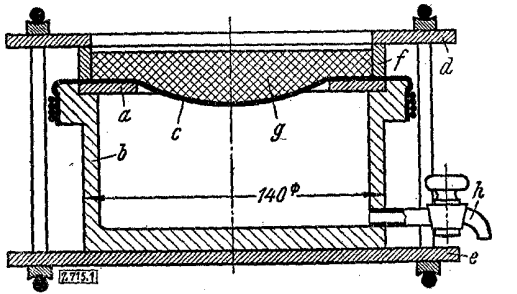

第 1 圖 $a$ 穴のある队盤 $b$ 黨 $c$ エ゙ム膜 $d, e$ 板 $f$ リング

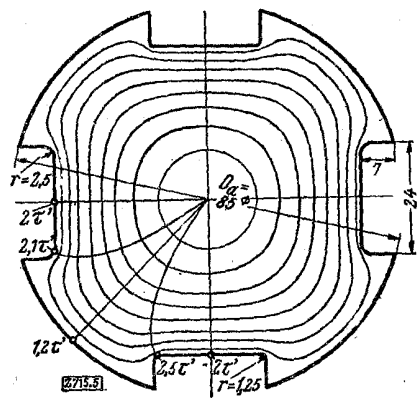
$g$ 叮定體諴塑性 物質 $h$ コック

第 2 圆

線を、文表面の傾科からその大きを撰定する。

第 2 圖以㨁径 $85 \mathrm{~mm}$ の炕棒に幅 $24 \mathrm{~mm}$ ，樑さ $7 \mathrm{~mm}$ の伪

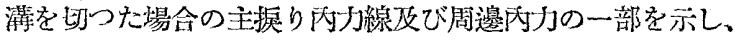

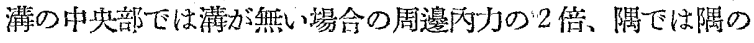
乎径が $2.5 \mathrm{~mm}$ の特 2.1 倍、 $1.25 \mathrm{~mm}$ の㭙 2.5 倍になる事

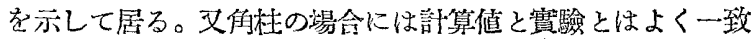
して居る事を示して居る。

(㽞㣜)

\title{
6. 蒸氛發生裝置
}

\section{[203] Port Washington 發電所に設置さ る、蒸气敘の胴}

[Edwin F. Cone, *Power Plant Engng., 1934-8, 頁 366 368.]

10 年以前に於る蒸气解の䏤は銅板鋲挍によるものが大部

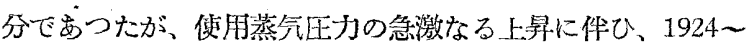
1925 年頃から一體火造式鋼耀䏤 (one-piece forged steel boiler shell) が造り始められ、續いて熔接技術の著しき發達 により、3〜4 年前から全熔接鋼胴が出現した。材料並に工 作に於て充分吟味した一體火造式の櫂榪は、鋲接の子のに比 し、その構造上弱點や蒸气叉は水の漏洩する盧れはなく、叉 壁を厚く乙强度を充分なものとすることが空易であるから、 工作費の高い缺點はもるが信賴度及び專俞は著しく埇加する ものである。

火造鋼䏤の大さは、設訊にもよるが、鋼塊の大きにより制 限される。現在壁の厚さは 1 in
又その內徍は 52 in に及ぶものが造られて居る。

目下建設中の Milwaukee Electric \& Light Company の Port Washington 發電所に据附汀られる 發生蒸气压力 1,890 1b/in ${ }^{2}$ の Stirling 罐 (Combustion Engineering Company 製造）に用ひられる3 簓の一體火造式胴は、Bethlehem Steel Company で造られて居るが、この中 2 筒の ものの長さは $62 \mathrm{ft}$, 殘りのもの小長さは $59 \mathrm{ft} 8 \mathrm{in}$, 壁の厚 怘は $5 \frac{1}{4} \mathrm{in}$, 胴の內径は 40 in で、一體火造式のもの〉中最 大の長さを有するものである。原鋼塊は㨁径 108 in の䥂型 にて造られたもので、重量は 392,0001b であつたが、鐙造 後に於ては $160,8001 \mathrm{~b}$ となり、仕上後のものは $143,717 \mathrm{lb}$

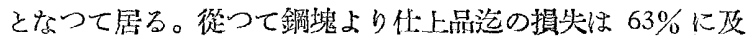
ぶことになる。かくの如琶大䁷の鋼塊より罐胴を火造方る ことは、洁金及び工作技微上劃期的の多のと云はれる。本交

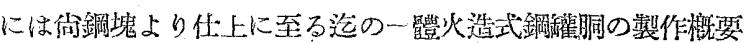
定記糟して居る。

(太时)

\section{7. 蒸氛原動機及び復水器}

\section{[204] 蒸气溫度 $1,000^{\circ} \mathrm{F}$ の Detroit} タービン設備の熱性能
[W. A. Carter 及び F. O. Ellenwood, *A. S. M. E. Trans., 1934-7, Vol. 57, No. 7, 頁 477 489, 圖 9; 傠諭 頁 489 496.]

昭和 9 仵 $11 \cdot$ 月丁 